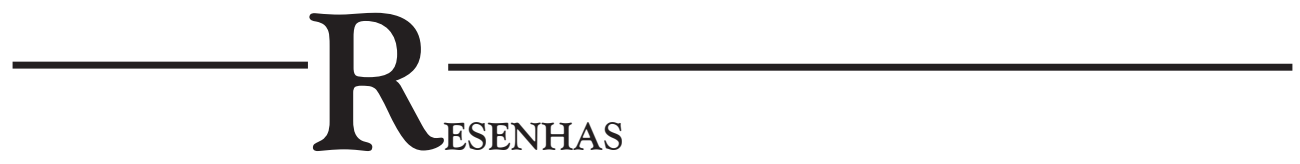

KILCOURSE, Carl. Taiping Theology: The Localization of Christianity in China, 1843-64. New York: Palgrave Macmillan, 2016, 281pp.

\title{
Cristianismo, glocalização E Rebelião na China: os taiping REVISITADOS
}

Breno Rodrigo de Oliveira Alencar*

*Instituto Federal do Pará - Belém

Pará - Brasil

Após sua transmissão para um novo ambiente cultural, a fé destrói e substitui as crenças e práticas religiosas anteriormente existentes ou é capaz de coexistir e até mesmo recriar-se através de tradições nativas pré-existentes?

Uma rebelião de camponeses chineses liderada por um místico autoproclamado, que tinha como propósito derrubar o sistema feudal local e substituí-lo por uma sociedade igualitária segundo os ideais do cristianismo primitivo, atraiu a atenção do historiador britânico Carl Kilcourse sobre esta questão. O resultado está contido neste livro, no qual ele reexamina a Rebelião Taiping (1850-1864) à luz do impacto exercido pelas missões protestantes na China pré-revolucionária.

Desafiando a associação entre cristianismo mundial e imperialismo cultural, o livro pretende ser também uma crítica ao que o autor qualifica como "suposições gerais" e "altamente enganosas" levantadas por antropólogos e historiadores que con- 
sideram a atuação dos missionários um serviço ao controle ideológico e de destruição cultural (ou genocídio) em todo o mundo.

Inserido na série de trabalhos desenvolvidos por Peter Phan e Dale Irving sobre cristandades do mundo e alinhado com as perspectivas teóricas dos historiadores Andrew Walls e Thomas Reilly, Kilcourse busca preencher a lacuna deixada pela localização do cristianismo na teologia, ética e práticas locais, examinando a interlocução que a cosmologia de povos nativos podem estabelecer com tradições regionais e nacionais. Para isso, dialoga com a historiografia padrão na qual os taipings são identificados como revolucionários camponeses, precursores do partido comunista chinês que tentou derrubar os "lacaios do imperialismo" (os membros da dinastia Qing) e lutar contra a "invasão bárbara de capitalistas estrangeiros". Ao revisar esta historiografia, porém, Kilcourse observa a negligência no tratamento dado à doutrina que Hong Xiuquan e seus seguidores mais próximos criaram, ignorando, assim, o incentivo que a mesma exerceu na reunião dos camponeses e no desenvolvimento da ideologia comunista ${ }^{1}$.

Seu trabalho contraria, portanto, muitos escritos ocidentais que, desde meados do século XIX, haviam negado a identidade cristã do movimento taiping. Alguns desses intérpretes, entre eles missionários e estudiosos do cristianismo e da religião, teriam se sentido ofendidos pelo desvio da ortodoxia promovido pelos rebeldes, reduzindo seu sistema de crenças a uma religião heterodoxa e sincrética. Outros simplesmente marginalizaram suas crenças acusando os rebeldes de serem nacionalistas anti-manchus dirigidos por um ódio racial aos governantes não-chineses da dinastia Qing. O efeito cumulativo dessa historiografia dominante, segundo o autor, é que estaríamos na completa ignorância sobre a teologia e a cultura religiosa que orientou a rebelião.

Assim, com o objetivo de localizar o movimento taiping dentro da história mais ampla do cristianismo mundial, Kilcourse se apoia em obras doutrinárias, poesias e documentos oficiais que descrevem as práticas rituais usadas pelas lideranças do movimento, e cuja vernacularização aponta como o cristianismo foi amplamente transformado por influências culturais que variavam da ortodoxia nacional ao sincretismo religioso.

Chamando a atenção para a transculturalização e globalização das dimensões teológicas, éticas e rituais implicadas nas missões protestantes do século XIX, o livro explora o conceito de glocalização como um importante arcabouço teórico. Para isso, enfatiza que o cristianismo presente na doutrina que governou a rebelião tinha como fundo a posição revolucionária de Hong e sua interpretação dos textos bíblicos:

A visão essencialista do cristianismo como uma religião passiva, de perdão e paciência mascara os temas bíblicos (em particular, a noção de Deus como um punidor destrutivo) e, portanto, indiretamente apoia a conclusão enganosa de que a vertente revolucionária no pensamento de 
Hong se desenvolveu fora - e até mesmo em oposição ao - do cristianismo [...]. O texto bíblico não apenas encorajou Hong a ver o poder imperial [Qing] como uma instituição blasfema [...], mas também inspirou sua crença central de que Deus interviria ativamente na história para destruir os manchus, adoradores de ídolos (tradução nossa) (p. 13-14).

O emprego do conceito de glocalização por Kilcourse se opõe, assim, à abordagem dada pelo irmãos Comaroff (2002), que elaboraram o conceito de "colonização da consciência" no intuito de demonstrar que o cristianismo moderno resulta da mediação cultural onde comunidades locais normalizam e particularizam a tradução e divulgação de textos bíblicos e narrativas religiosas conectando as visões exógenas aos seus próprios mundos através do cotidiano e de condições locais. $\mathrm{O}$ conceito de glocalização, portanto, se concentra mais precisamente no objeto do processo de localização de um produto, ideologia ou instituição disseminada globalmente em múltiplas e variadas configurações culturais ao redor do mundo. Nesta perspectiva, a localização, como processo transformador, ocorre quando um objeto, uma ideia ou uma instituição estrangeira é levado para um novo ambiente cultural, exposto a influências locais e, assim, transformado em uma expressão original da cultura nativa. A glocalização do cristianismo seria, então, um processo constituído por quatro estágios: (1) a difusão global de textos e símbolos cristãos através de missões mundiais; (2) a vernacularização de textos cristãos dentro de contextos linguísticos e culturais específicos; (3) a difusão de textos cristãos traduzidos entre populações nativas; e (4) sua localização por receptores locais da literatura cristã vernacularizada.

Fornecendo uma nova - e muito menos "condenatória" - perspectiva sobre o impacto cultural das missões cristãs, este quadro teórico também se opõe à ideia de que os taiping distorceram o cristianismo para promover uma luta de classes baseada na oposição às "classes exploradoras" (incluindo proprietários e capitalistas comerciais) da China do século XIX. Ainda que aceita, esta tese é duramente criticada ao longo do livro por se tratar do efeito cumulativo e dominante de tendências historiográficas influenciadas por suposições de missionários protestantes britânicos e americanos que trabalharam na China (e, em alguns casos, visitaram os territórios taiping localizados ao longo do Rio Azul durante a década de 1850). A mesma crítica é dirigida aos acadêmicos e estudiosos do cristianismo e da doutrina taiping, que os inserem em uma narrativa linear do declínio feudal e do progresso revolucionário rumo ao socialismo, identificando o grupo como formado por opositores da dinastia Qing ou ancestrais revolucionários dos comunistas chineses. Ao fazerem isso, os historiadores teriam ofuscado o que para Kilcourse é o verdadeiro caráter do movimento: restaurar a posição e o título divino do antigo Deus chinês usurpado pelo poder imperial.

Como produto da crítica ao confucionismo, assim como da sobreposição terminológica entre a Bíblia traduzida e os clássicos chineses, os seis capítulos que compõem o livro se desdobram em demonstrar que, ao aderirem ao cristianismo, os 
taiping encontraram uma maneira de reconhecer, ao invés de destruir, uma tradição cultural chinesa antiga (e historicamente registrada).

A forma localizada que o cristianismo assume sob esta perspectiva permite concluir que Carl Kilcourse procurou desafiar a historiografia convencional sobre a China, oferecendo aos pesquisadores da China imperial, do cristianismo chinês e do cristianismo mundial um estudo de caso bem articulado sobre a localização do cristianismo através de escritos locais. Permite ainda problematizar o desenvolvimento de uma cosmologia teológica, cujo trabalho de tradução e disseminação por meio de textos bíblicos em regiões afastadas do centro de poder levou o confucionismo - a principal arma de resistência à influência ocidental sobre a China - a ser assimilado no processo de reinterpretação bíblica (em particular, a sua doutrina da piedade filial). Esta imbricação assinala também a distinção entre as intenções dos missionários e os resultados de seu trabalho de evangelização, pois mesmo que eles estivessem em busca de seguidores passivos, que aceitassem sua autoridade espiritual e a versão ortodoxa do cristianismo, o desejo de controlar o pensamento da população local era contrariado pelo significado pessoal e político que os convertidos davam às verdades transmitidas.

\section{Referências}

KILCOURSE, Carl. Taiping Theology: The Localization of Christianity in China, 1843-64. New York: Palgrave Macmillan, 2016, 281pp.

\section{Nota}

${ }^{1}$ Em linhas gerais, a doutrina taiping estava caracterizada na fraternidade humana em Deus como fonte pessoal, porém transcendente, de mudança histórica e poder terreno; na existência de uma família espiritual universal; e no princípio moral e político de que a piedade filial (xiao) deveria ser convertida em lealdade ao soberano.

Breno Rodrigo de Oliveira Alencar (breno.alencar@ifpa.edu.br) 